\title{
Preliminary Phytochemical Studies, GC-MS Analysis and In vitro Antioxidant Activity of Selected Medicinal Plants and its Polyherbal Formulation
}

\author{
Shalini $\mathbf{K}^{1}$, llango $\mathbf{K}^{2, *}$
}

\section{Shalini $\mathrm{K}^{1}$, Ilango $\mathrm{K}^{2, *}$}

'Division of Pharmacognosy and

Phytochemistry, Interdisciplinary Institute of Indian System of Medicine (IIISM), SRM Institute of Science and Technology, Kattankulathur- 603 203, Chengalpattu (Dt) Tamil Nadu, INDIA.

${ }^{2}$ Department of Pharmaceutical Chemistry, SRM College of Pharmacy, SRM Institute of Science and Technology

Kattankulathur-603 203, Chengalpattu (Dt), Tamil Nadu, INDIA.

\section{Correspondence}

\section{llango $\mathbf{K}$}

Department of Pharmaceutical Chemistry, SRM College of Pharmacy SRM Institute of Science and Technology, Kattankulathur - 603 203, Chengalpattu (Dt), Tamil Nadu, INDIA.

E-mail: ilangok1@srmist.edu.in

History

- Submission Date: 28-12-2020;

- Review completed: 12-02-2021;

- Accepted Date: 01-03-2021.

DOI : 10.5530/pj.2021.13.83

Article Available online http://www.phcogj.com/v13/i3

\section{Copyright}

(c) 2021 Phcogi.Com. This is an openaccess article distributed under the terms of the Creative Commons Attribution 4.0 International license.

\begin{abstract}
Background: Novel polyherbal formulation (PHF) is the utilization of more than one herb in the preparation of herbal medication. The thought is found in the conventional system of medicine where the variety of herbs in a specific proportion of illness. Because of synergism, polyherbalism presents a few advantages which aren't accessible in single herbal medication. It is utilized in these medications for the treatment of numerous sicknesses including antioxidants. Objective: To develop a phytochemical screening and GC-MS analysis of Novel Polyherbal formulation for In vitro antioxidant activity. Materials and Methods: Macroscopical, preliminary phytochemical, quantitative phytoconstituents, and In-vitro antioxidant activity of all the individual extract and polyherbal formulation was done by chemical method. Identification of phytoconstituents with the aid of Gas chromatography - Mass spectroscopy (GC-MS). Results: Macroscopical study and physicochemical examination, for example, ash value, extractive value, loss on drying, and $\mathrm{pH}$ were reported to $A$. racemosus, $B$. variegata, C. bonducella, S. asoka, and S. racemosus and novel polyherbal formulation. Qualitative phytochemical investigation revealed the presence of alkaloids, flavonoids, gums \& mucilage, carbohydrates, steroids, proteins \& amino acids, fats \& fixed oils, glycoside, phenols, and saponins. Quantitative estimation such as TAC, TFC, TGC, TSC, and TPC was showed positive results. All the individual extract and PHF were subjected to GC-MS analysis. All the individual extract and polyherbal formulation displayed strong antioxidant activity. Conclusions: To conclude the PHF was reported that high level of bioactive contents present and strong antioxidant activity in contrast to the preferred ascorbic acid. The GC-MS uncovered the presence of bioactive compounds and these compounds are suggested to treat antibacterial, antioxidant, anti-inflammatory, and antiviral, anti-tumor, anti-proliferative activity, and antifungal activity.

Key words: Phytochemical, Macroscopical, Antioxidant, Polyherbal formulation, GC-MS analysis.
\end{abstract}

\section{INTRODUCTION}

The conventional medication everywhere in the world is nowadays uncovered by an in-depth movement of researchers on various plant species and their restorative principles. The conventional medication everywhere in the world is these days revealed by a substantial action researcher on various plant species and their therapeutic principles. Plants contain phytochemicals with various bioactivities including antioxidant, anti-inflammatory, and anticancer activities. Right now, about $25 \%$ of the active component was recognized from plants that are utilized as prescribed medicines. ${ }^{1}$ Oxidative stress is a critical danger factor in the pathogenesis of various chronic diseases. An antioxidant can be extensively characterized as the substance that delays or impedes oxidative harm to an objective particle. The most characteristic of an antioxidant is its capacity to trap free radicals. ${ }^{2}$ Natural antioxidants can shield the physical body from free radicals and retard the advancement of numerous long-term diseases. Because of the impact on the immune structure of the human body, there is a requirement for natural antioxidants agents when contrast to artificial antioxidants (harmful for people). Plants contain numerous constituents with a nearby actual effect on body tissues, and therefore the topical use of herbal remedies is among the foremost noticeable within the simplest conventional health care system. To help the usage of selected plant extracts within the conventional system of medicine, the antioxidant capability of the rhizome of Asparagus racemosus, the bark of Bauhinia variegata, seed kernel of Caesalpinia bonducella, the bark of Saraca asoka, and hardwood of Symplococus racemosus was examined.

In the current study, five different herbal plants were chosen for the preparation of polyherbal formulation and standardization in terms of macroscopical, physicochemical, qualitative, and quantification of bioactive constituents. All the individual plant extract and the polyherbal formulation were subjected to GC-MS analysis to consider the phytocompounds present and the evaluation of antioxidant activity was studied by the DPPH, radical scavenging, and hydrogen peroxide assay.

Cite this article: Shalini K, Ilango K. Preliminary Phytochemical Studies, GC-MS Analysis and In vitro Antioxidant Activity of Selected Medicinal Plants and its Polyherbal Formulation. Pharmacog J. 2021;13(3): 648-59. 
Asparagus racemosus (family Asparagaceae) commonly referred to as Shatavari, Satawar, Thaneervitan kilangu, Satamuli, is an indigenous herb found in India. Shatavari is a tremendous herb in Ayurveda, is understood as the Queen of herbs since it promotes love and affection. Medicinal uses of Shatavari are mentioned referred to as nervous disorders, diuretic, stomachic, dyspepsia, diarrhea, dysentery, tumors, carminative, inflammation, galactagogue, hyperdipsia, stomachic, neuropathy, antiseptic, hepatopathy, cough, bronchitis, hyperacidity, and tonic. Reported Pharmacological activities of Shatavari contain antiulcer, antitussive, adaptogenic, antioxidant, antidiabetic, antiulcer, antidiarrhoeal, antiprotozoal, antihepatotoxic, antineoplastic, cardiovascular effects, a versatile female tonic, and immunomodulatory activities. ${ }^{4}$

Bauhinia variegata (family Leguminosae) is usually referred to as the Orchid tree, Mandarai, Mountain ebony, and camel's food. It had been in their showy owers and decorative foliage. It had been native to the Southeast and grows during a tropical and subtropical climate. Whole plant parts having medicinal value. Traditional uses of mountain ebony were astringent, tonic, bronchitis, leprosy, tumor, anthelmintic, diarrhea, piles, and antidiabetic. Pharmacological activities of Bauhinia variegata showed that antioxidant, anticancer, hypolipidemic, antiinflammatory, antiulcer, antimicrobial, antiulcer, hepatoprotective, molluscicidal, nephroprotective, immunomodulating, and wound healing effects. ${ }^{5}$

Caesalpinia bonducella (family Caesalpiniaceae) may be a thorny bush broadly dispersed everywhere within the world uniquely, in India, Srilanka, Andaman, and therefore the Nicobar Islands, in India especially originate in a humid region. All parts of the plant have valuable medicinal plant; it had been utilized in traditional system of medicine. Reported medicinal properties of Caesalpinia bonducella was anti-inflammatory, antitumor, antimalarial, antifungal, antidiabetic, antispasmodic, antioxidant, antiproliferative, larvacidal, muscle contractile, anticonvulsants, adaptogenic, anxiolytic, antipsoriatic, antifilarial, and antispasmodic. ${ }^{6}$

Saraca asoka (family Caesalpiniaceae) generally called Ashoka may be a Sanskrit word that meaning "without sorrow" or which that provides no grief. It's also referred to as Asogam (Tamil), Asokam (Malayalam), Asokapatta (Telugu), and Ashok (Kashmiri). Reported pharmacological activities of Ashoka included anti oxytoxic, anti-microbial activity, antimenorrhagic, and anti-cancer. ${ }^{7}$

Symplococus racemosa (family Symplocaeae) is usually referred to as Lodhra in Sanskrit. Traditional use of Symplocous racemosa was stomachic, expectorant, astringent, anti-inflammatory, febrifuge, hemostatic, and constipating. It's useful in leprosy, disease of the skin, tumors, asthma, bronchitis, arthritis, fever, pimples, hemorrhages, diarrhea, baldness, ear diseases, elephantiasis, and gonorrhea. ${ }^{8}$

\section{MATERIALS AND METHODS}

\section{Collection and authentication of plants}

All the ingredients of the Polyherbal formulation are collect and purchased from different parts of Chennai. Their authentications were confirmed in the Botanical Survey of India, Coimbatore by comparing their morphological and microscopical characters with those given in the ancient literature and books.

\section{Macroscopic analysis}

Organoleptic and macroscopic analysis of A. racemosus, B. variegata, C. bonducella, S. asoka, and S. racemosus were performed and the parameters evaluated for the different parts of color, odor, taste, shape, and texture were observed and noted. ${ }^{9,10}$

\section{Method of preparation polyherbal formulation}

All the selected medicinal plant parts were cleaned by utilizing a sterilized fabric cloth to get rid of dirt and via air, blustering to eliminate minute sand particles. Each $1000 \mathrm{mg}$ of a polyherbal formulation contains a different quantity of Asparagus racemosus (root), Bauhinia variegata (wood), Caesalpinia bonducella (seed kernel), Saraca asoka (Bark), and Symplococus racemosus (wood). Each plant material was size reduced using the blender. After that sieved in separately all the plant materials it was using sieve no 60 . Each blended and dried powder of individual plant materials was weighed in the required quantity. After that, all the individual powder was mixed in a geometrical type of mixing. $10 \mathrm{~g}$ of that polyherbal mixture was macerated with hydroalcoholic solvent (30:70) with infrequent stirring for $72 \mathrm{hrs}$. After $72 \mathrm{hrs}$ the suspensions were shifted through a fine muslin fabric cloth and the collected filtrate was evaporated to dryness kept at desiccator. The yield of the collected polyherbal formulation was found to be $15.47 \%$ and was stored in an air-tight container for further analysis. ${ }^{11}$

\section{Physicochemical parameters}

Physiochemical Constants of the Individual drugs and Polyherbal formulations have been done to estimate the quality and purity of the powder drugs. Physiochemical constants include Ash value it represents the occurrence of inorganic salts exiting in the plant material. The extractive values included such as water-soluble and alcohol soluble extractive values were determined. Loss on drying and $\mathrm{pH}$ was carried out. The information composed since this evaluation was helpful for standardization and obtaining the quality standards for crude drugs as well as for polyherbal formulation. Determinations of these physiochemical constants were done according to the methodology referenced by WHO guidelines. ${ }^{11,12}$

\section{Preliminary phytochemical screening}

All the individual plant extracts and Polyherbal mixer were subjected to screen the preliminary phytochemicals such as alkaloids, flavonoids, glycosides, phenolic compounds, saponins, terpenoids, steroids, tannins, fatty acids, protein, and carbohydrate according to the standard methods. ${ }^{10}$

\section{Quantitative phytochemical analysis}

A systematic and complete investigation of crude drugs should contain a detailed study of both primary and secondary metabolites derivative as an outcome of plant metabolism. All the individual extract and polyherbal were subjected to qualitative and quantitative phytochemical analysis such as alkaloid, flavonoid, steroid, saponin, phenolics, gums \& mucilage, fats \& fixed oils, carbohydrates, proteins \& amino acids, and volatile oils were done using the prescribed method.

\section{Determination of total flavonoid content (TFC)}

Determination of total flavonoid content depended on the aluminium chloride $\left(\mathrm{AlCl}_{3}\right)$ method. ${ }^{13}$ Taken a $50 \mathrm{mg}$ standard quercetin component and dissolved in $50 \mathrm{ml}$ methanol solution and different aliquots of $5-25 \mu \mathrm{g} / \mathrm{ml}$ were prepared in methanol. It was utilized as a standard solution. $10 \mathrm{mg}$ of dried individual plant extract and polyherbal formulation were dissolved in $10 \mathrm{ml}$ of methanol and filter. $3 \mathrm{ml}$ of $(1 \mathrm{mg} / \mathrm{ml})$ of this extract was utilized for the estimation of flavonoids. In the last advance, take $3 \mathrm{ml}$ of plant extract or standard and add $1 \mathrm{ml}$ of $2 \% \mathrm{AlCl}_{3}$ methanolic solution. This combination of the mixture is allowed to stand for $60 \mathrm{~min}$ at room temperature. Then absorbance was measured at $420 \mathrm{~nm}$ by utilizing a spectrophotometer. 


\section{Determination of total alkaloid content (TAC)}

The individual plant extract and polyherbal formulation $(1 \mathrm{mg} / \mathrm{ml})$ were thawed in $2 \mathrm{~N} \mathrm{HCL}$ and afterward shifted to a separating tube. The $\mathrm{pH}$ of the phosphate buffer solution was adjusted to neutral with $0.1 \mathrm{~N} \mathrm{NaOH}$. $1 \mathrm{ml}$ of sample solution was lifted to a separating funnel and afterward, $5 \mathrm{ml}$ of BCG solution together with $5 \mathrm{ml}$ of phosphate buffer were added. The combined blend was shaken were gathered in a $10 \mathrm{ml}$ volumetric jar and weakened to volume with chloroform. The absorbance of the complex in chloroform was estimated at $470 \mathrm{~nm} .{ }^{14}$

\section{Determination of total steroidal content (TSC)}

The determination of steroidal substance was done by LiebermannBurchard colorimetric assay method with minor modifications utilizing as a standard. ${ }^{15}$ The Liebermann Burchard reagent was set up by adding $5 \mathrm{ml}$ of concentrated sulphuric corrosive to $50 \mathrm{~mL}$ of acidic anhydride solution. All the extracts and polyherbal formulation were diluted with chloroform and to the chloroform extract, freshly prepared Liebermann-Burchard reagent was added and estimated at $650 \mathrm{~nm}$ against a reagent blank. Steroidal content was expressed in $\mathrm{mg}$ of cholesterol equal to $g$ of dry load of the extract.

\section{Determination of total glycosidal content (TGC)}

The determination of glycoside content was completed utilizing a Baljet reagent indicated by the method described in Nandhini et al 20201 $\mathrm{mL}$ of extract was added to the solution of Baljet reagent containing picric acid and $0.1 \mathrm{~N}$ sodium hydroxide with the proportion of 95:5. The solution was permitted to incubate in a dark chamber for $60 \mathrm{~min}$ and additionally diluted to $15 \mathrm{ml}$ with distilled water and absorbed at $495 \mathrm{~nm}$. Digitoxin was utilized as a standard for assurance of glycoside and the results were communicated in $\mathrm{mg}$ of digitoxin equal to $\mathrm{g}$ of the dry weight of the extract. ${ }^{16,17}$

\section{Determination of total saponin content (TSC)}

The determination of saponin content was based on Nandhini et al 2020 utilizing diosgenin as a standard solution. ${ }^{17} 1 \mathrm{~mL}$ of $80 \%$ aqueous methanol was added to $1 \mathrm{~mL}$ of diluted extracts and polyherbal formulation followed by $1 \mathrm{~mL}$ of $72 \%$ sulphuric acid was added to the sides of the test tubes. The blend was warmed on a water bath $60^{\circ} \mathrm{C}$ for $10 \mathrm{~min}$ and the absorbance was recorded at $544 \mathrm{~nm}$ against $80 \%$ methanol as a blank solution. The total saponin content was determined utilizing a standard calibration curve of diosgenin with a concentration range of $20-200 \mu \mathrm{g} / \mathrm{mL}$ solution and the outcomes were expressed in $\mathrm{mg}$ of diosgenin equivalent to $g$ of the dry weight of the extract.

\section{Determination of total phenolic content (TPC)}

The microplate total phenolic content method was determined by the 96 - well microplate Folin-Ciocalteu procedure adjusted from Sembiring et al with specific alterations. ${ }^{18} \mathrm{~A}$ whole of $25 \mu \mathrm{L}$ of the individual extract and polyherbal formulation (diluted form) were blended in with $100 \mu \mathrm{L}$ of 1:4 weakened Folin-Ciocalteu reagent and shaken for $60 \mathrm{sec}$ in a level base 96-well microplate. The collective blend was left for 4 mins and afterward, $75 \mu \mathrm{L}$ of sodium carbonate solution $(100 \mathrm{~g} / \mathrm{L})$ was added and the combination was shaken at a medium constant speed for $1 \mathrm{~min}$. After $2 \mathrm{~h}$ at room temperature, the absorbance was assessed at $765 \mathrm{~nm}$ utilizing the microplate reader. The absorbance of a similar response with ethanol rather than the sample and standard was deducted from the absorbance of calibration. Complete phenolic contents were stated as mg Gallic Acid Equivalents (GAE) per g of extracted plant samples and polyherbal formulation.

\section{GC-MS analysis}

For the identification of the phytochemical compounds, the hydroalcoholic extract of individual plants and PHF was exposed to the examination of GC-MS analysis. Gas chromatography-Mass spectrometry (GC/MS) was carried out in the Shimadzu 17A GC combined with Shimadzu QP2010 plus (quadrupole) Mass Spectrometer (Shimadzu, Japan), furnished with EI and a fused silica column DB-5 $(30 \mathrm{~m} \times 0.25 \mathrm{~mm}$ i.d) of $0.25 \mu \mathrm{m}$ film thickness was required. The oven temperature at $500^{\circ} \mathrm{C}$ for 5 minutes and then modified from $50-2800^{\circ} \mathrm{C}$ for 40 minutes. High pure Helium was used as a carrier gas for this analysis. The flow rate of helium gas was used at $2 \mathrm{~mL} / \mathrm{min}$, with the split proportion of 1:30 mode was utilized for sample injection of $1 \mu \mathrm{l}$ and ionization voltage of MS-analysis was controlled by EI procedure at 70 $\mathrm{eV}$. The Phytochemical constituents were recognized by associating the results of the mass spectrum with the inbuilt NIST library database. ${ }^{19-22}$

\section{In vitro antioxidant activity}

\section{DPPH method}

All the individual plant extracts and PHF was subjected to the DPPH free radical scavenging assay was determined by the technique depicted by the method Madhu SE et al ${ }^{23}$ slight adjustments. This DPPH assay quantifies the capacity of all the extract and polyherbal formulation below assessment to scavenge the free radicals. All the five extracts and polyherbal formulation were calculated for the antioxidant activity against DPPH free radical scavenging assay. The stock solution of all the extracts and standard solution (ascorbic acid) was prearranged for the concentration of $1 \mathrm{mg} / \mathrm{ml}$. Three serial dilutions of each extract and polyherbal formulation and standard ascorbic acid were made $(12.5 \mu \mathrm{g} / \mathrm{ml}, 25 \mu \mathrm{g} / \mathrm{ml}, 50 \mu \mathrm{g} / \mathrm{ml}, 100 \mu \mathrm{g} / \mathrm{ml}$, and $200 \mu \mathrm{g} / \mathrm{ml})$. Every $3 \mathrm{ml}$ of each extract and the standard solution were added to the $1 \mathrm{ml}$ of DPPH solution $(0.1 \mathrm{Mm} / \mathrm{L})$. This mixed solution was shaken forcefully and incubated for $20 \mathrm{~min}$ in a dark room. This incubated solution was estimated the absorbance was noted at $517 \mathrm{~nm}$. The whole procedure was repeated three times. The $\mathrm{IC}_{50}$ value of $\mathrm{DPPH}$ assay was calculated using the below formula:

$\%$ Inhibition of DPPH assay $=($ Ac-As/Ac $) \times 100$

Where $\mathrm{Ac}=$ Absorbance of Control

As $=$ Absorbance of Standard $/$ Sample

\section{Hydrogen peroxide assay}

The ability of all the individual extracts and the polyherbal formulation was estimated according to the method given by Ruch RJ et al and Saumya SM et al. ${ }^{24,25}$ Using phosphate buffer $\mathrm{H}_{2} \mathrm{O}_{2}$ solution was prepared and maintain $\mathrm{pH}$ at 7.4. All the individual extracts and PHF $(12.5 \mu \mathrm{g} / \mathrm{ml}, 25 \mu \mathrm{g} / \mathrm{ml}, 50 \mu \mathrm{g} / \mathrm{ml}, 100 \mu \mathrm{g} / \mathrm{ml}$,and $200 \mu \mathrm{g} / \mathrm{ml})$ were added $0.6 \mathrm{ml}$ of $\mathrm{H}_{2} \mathrm{O}_{2}$ solution. Ascorbic acid was used as the standard. The absorbance of $\mathrm{H}_{2} \mathrm{O}_{2}$ at $230 \mathrm{~nm}$ was estimated after against without adding $\mathrm{H}_{2} \mathrm{O}_{2}$ solution and associated with ascorbic acid was used as the reference compound.

\section{$\mathrm{H}_{2} \mathrm{O}_{2}$ activity $(\%)=($ Ac-As/Ac $) \times 100$}

Where $\mathrm{Ac}=$ Absorbance of Control

As $=$ Absorbance of Standard / Sample

\section{Reducing power assay}

Each extract and PHF was subjected to the reducing power assay based on the method derived from Gülçin İ et al, Meriga Bet al. ${ }^{26,27}$ Each sample and standard ascorbic acid $(12.5 \mu \mathrm{g} / \mathrm{ml}, 25 \mu \mathrm{g} / \mathrm{ml}, 50 \mu \mathrm{g} / \mathrm{ml}, 100$ $\mu \mathrm{g} / \mathrm{ml}$, and $200 \mu \mathrm{g} / \mathrm{ml}$ ) was added $1 \mathrm{ml}$ of distilled water this mixture was sonicated at 20 mins for aqueous extraction. In this above solution mixed with $2.5 \mathrm{ml}$ of phosphate buffer $(0.2 \mathrm{~mol} / \mathrm{L}, \mathrm{pH} 6.6)$ and $2.5 \mathrm{ml}$ of $1 \%$ potassium ferricyanide $[\mathrm{K} 3 \mathrm{Fe}(\mathrm{CN}) 6]$. The combined solution was incubated for $20 \mathrm{~min}$ at $50^{\circ} \mathrm{C}$. $2.5 \mathrm{ml}$ of above the upper layer solution was blended in with $2.5 \mathrm{ml}$ of distilled water and $0.5 \mathrm{ml}$ of ferric chloride $(0.1 \%)$. The absorbance was estimated at $700 \mathrm{~nm}$. 


\section{RESULTS AND DISCUSSION}

\section{Phytochemical analysis}

\section{Macroscopical evaluation}

The macroscopical evaluation was carried out to assess the color, odor, taste, shape, and texture of the individual drugs, and the polyherbal formulation was observed and recorded in Table 1.

\section{Physicochemical Analysis}

Physicochemical analysis of individual ingredients and PHF was studied and represented with standard deviation. In physicochemical evaluation such as total ash, water-soluble ash, acid insoluble ash, water-soluble extractive value, ethanol-soluble extractive value, loss on drying, and $\mathrm{pH}$ were evaluated results were given in Table 2 . The ash values demonstrate the presence of inorganic salts present in the drug. The extractive values (water and ethanol soluble extractive value) were resolved. The data gathered from this evaluation was helpful for standardization and obtaining the quality standards for a crude drug as well as for PHF formulations. Determination of these physiochemical constants was according to systems referred to as per WHO guidelines.

\section{Preliminary phytochemical screening}

Preliminary phytochemical screening of the individual drugs and polyherbal formulation confirmed the presence of phytoconstituents such as flavonoids, alkaloids, carbohydrates, gums \& mucilage, fats \& fixed oils, steroids, glycosides, phenols, saponins but no volatile oils (Table 3).

\section{Determination of bioactive contents}

The quantitative determination of bioactive contents includes alkaloid, flavonoid, glycoside, steroid, saponin, and phenol were determined in the hydroalcoholic extract of individual drugs, and PHF results were given in Figure 1 and described in Table 4.

Alkaloids were equivalent to Atropine, phenolics equivalent to Gallic acid, flavonoids equivalent to Catechin, glycosides equivalent to Digitoxin, steroids equivalent to Cholesterol, and saponins equivalent to Diosgenin.

\section{GC-MS profile}

The GC-MS analysis in the hydroalcoholic extract of Asparagus racemosus showed the presence of major phytochemical compounds

Table 1: Organoleptic Description of Individual plant part in polyherbal formulation.

\begin{tabular}{|c|c|c|c|c|c|}
\hline Parameters & AR & BV & $\mathrm{CB}$ & SA & SR \\
\hline Part to be used & Root & Bark & Seed & Bark & Wood \\
\hline Color & $\begin{array}{l}\text { Brown } \\
\text { colored }\end{array}$ & $\begin{array}{l}\text { Externally brownish and internally } \\
\text { light reddish-brown. }\end{array}$ & $\begin{array}{l}\text { Greenish gray to bluish- } \\
\text { gray }\end{array}$ & Grayish brown & Grayish brown \\
\hline Odor & Characteristic & Characteristic & Characteristic & Aromatic & Characteristic \\
\hline Taste & Mucilaginous & $\begin{array}{c}\text { Mucilaginousfollowed by bitter } \\
\text { sensation. }\end{array}$ & Bitter & Astringent & Astringent \\
\hline Shape & Tuberous \& elongated & Curved & Globules or round & Vary in size & Slightly Curved \\
\hline Texture & $\begin{array}{l}\text { Soft \& contains epidermal } \\
\text { hairs }\end{array}$ & Hard surface & Smooth and shiny & Hard and strong & Smooth \\
\hline
\end{tabular}

AR-Asparagus racemosus, BV-Bauhinia variegata, CB-Caesalpinia bonducella, SA-Saraca asoka, SR-Symplococus racemosus, PHF-Polyherbal formulation

Table 2: Physiochemical constants.

\begin{tabular}{|c|c|c|c|c|c|}
\hline Parameters & AR & BV & CB & SA & SR \\
\hline Total ash $(\% w / w)$ & $3.00 \pm 0.143$ & $9.5 \pm 1.34$ & $3.52 \pm 0.241$ & $4.70 \pm 0.183$ & $10.03 \pm 1.003$ \\
\hline Water soluble ash (\%w/w) & $1.83 \pm 1.271$ & $3.48 \pm 0.28$ & $2.03 \pm 1.002$ & $2.62 \pm 0.382$ & $3.12 \pm 2.041$ \\
\hline Acid insoluble ash (\%w/w) & $0.29 \pm 0.302$ & $0.63 \pm 0.07$ & $0.58 \pm 0.042$ & $0.15 \pm 0.041$ & $0.37 \pm 1.052$ \\
\hline Water soluble Extractive value (\%w/w) & $12.92 \pm 0.824$ & $14.03 \pm 1.002$ & $16.54 \pm 1.801$ & $10.71 \pm 1.031$ & $9.17 \pm 0.401$ \\
\hline Ethanol soluble extractive value (\%w/w) & $7.82 \pm 1.026$ & $6.6 \pm 0.062$ & $7.53 \pm 0.034$ & $8.42 \pm 0.721$ & $6.87 \pm 0.521$ \\
\hline Loss on dying $(\% w / w)$ & $5.12 \pm 0.407$ & $4.38 \pm 1.034$ & $5.03 \pm 0.104$ & $3.55 \pm 0.242$ & $3.82 \pm 1.052$ \\
\hline pH & $5.03 \pm 0.381$ & $5.14 \pm 0.241$ & $4.13 \pm 1.316$ & $5.77 \pm 0.469$ & $4.89 \pm 0.041$ \\
\hline
\end{tabular}

Values were in mean \pm standard deviation, $\mathrm{n}=3$

AR-Asparagus racemosus, BV-Bauhinia variegata, CB-Caesalpinia bonducella, SA-Saraca asoka, SR-Symplococus racemosus, PHF-Polyherbal formulation

Table 3: Preliminary phytochemical analysis.

\begin{tabular}{|c|c|c|c|c|c|c|}
\hline Test of constituents & AR & BV & CB & SA & SR & PHF \\
\hline Flavonoids & - & + & + & + & + & ++ \\
\hline Alkaloids & - & + & - & + & + & ++ \\
\hline Carbohydrates & + & + & + & + & + & + \\
\hline Gums \& Mucilage & + & + & + & + & + & + \\
\hline Proteins \& Amino acids & + & + & + & + & + & + \\
\hline Fats and fixed oils & - & - & + & - & - & + \\
\hline Steroids & + & + & + & + & + & ++ \\
\hline Glycosides & _ & + & - & + & + & + \\
\hline Phenols & + & - & + & + & - & + \\
\hline Saponins & + & - & + & - & - & + \\
\hline Volatile oils & - & - & - & - & - & - \\
\hline
\end{tabular}

(+)- Present; (++)- Strongly present; (-)- Absence

AR-Asparagus racemosus, BV-Bauhinia variegata, CB-Caesalpinia bonducella, SA-Saraca asoka, SR-Symplococus racemosus, PHF-Polyherbal formulation 
Table 4: Determination of bioactive contents ( $\mathrm{mg} / \mathrm{g})$.

\begin{tabular}{|c|c|c|c|c|c|c|}
\hline Quantitative parameters & Alkaloid & Flavonoid & Glycoside & Steroid & Saponin & Phenol \\
\hline AR & ND & $30.43 \pm 0.97$ & ND & $63.61 \pm 1.17$ & $55.6 \pm 0.89$ & $69.1 \pm 0.42$ \\
\hline BV & $82.55 \pm 0.78$ & $68.36 \pm 0.77$ & $47.59 \pm 1.12$ & $72.03 \pm 0.92$ & $24.61 \pm 0.93$ & $36.53 \pm 0.68$ \\
\hline $\mathrm{CB}$ & ND & $18.31 \pm 0.78$ & ND & $63.79 \pm 0.97$ & $26.9 \pm 0.58$ & $74.32 \pm 0.54$ \\
\hline SA & $96.07 \pm 0.64$ & $74.1 \pm 0.67$ & $62.76 \pm 1.01$ & $51.42 \pm 1.15$ & $33.45 \pm 1.13$ & $20.59 \pm 0.44$ \\
\hline SR & $66.49 \pm 0.99$ & $85.27 \pm 0.57$ & 79.261 .36 & $80.53 \pm 1.4$ & $47.18 \pm 0.62$ & $38.71 \pm 0.62$ \\
\hline PHF & $99.93 \pm 0.78$ & $87.26 \pm 0.92$ & $80.87 \pm 0.36$ & $90.52 \pm 0.84$ & $60.2 \pm 0.98$ & $66.62 \pm 0.89$ \\
\hline
\end{tabular}

Values were in mean \pm standard deviation, $\mathrm{n}=3$

ND- Not Detected, AR-Asparagus racemosus, BV-Bauhinia variegata, CB-Caesalpinia bonducella, SA-Saraca asoka, SR-Symplococus racemosus, PHF-Polyherbal formulation

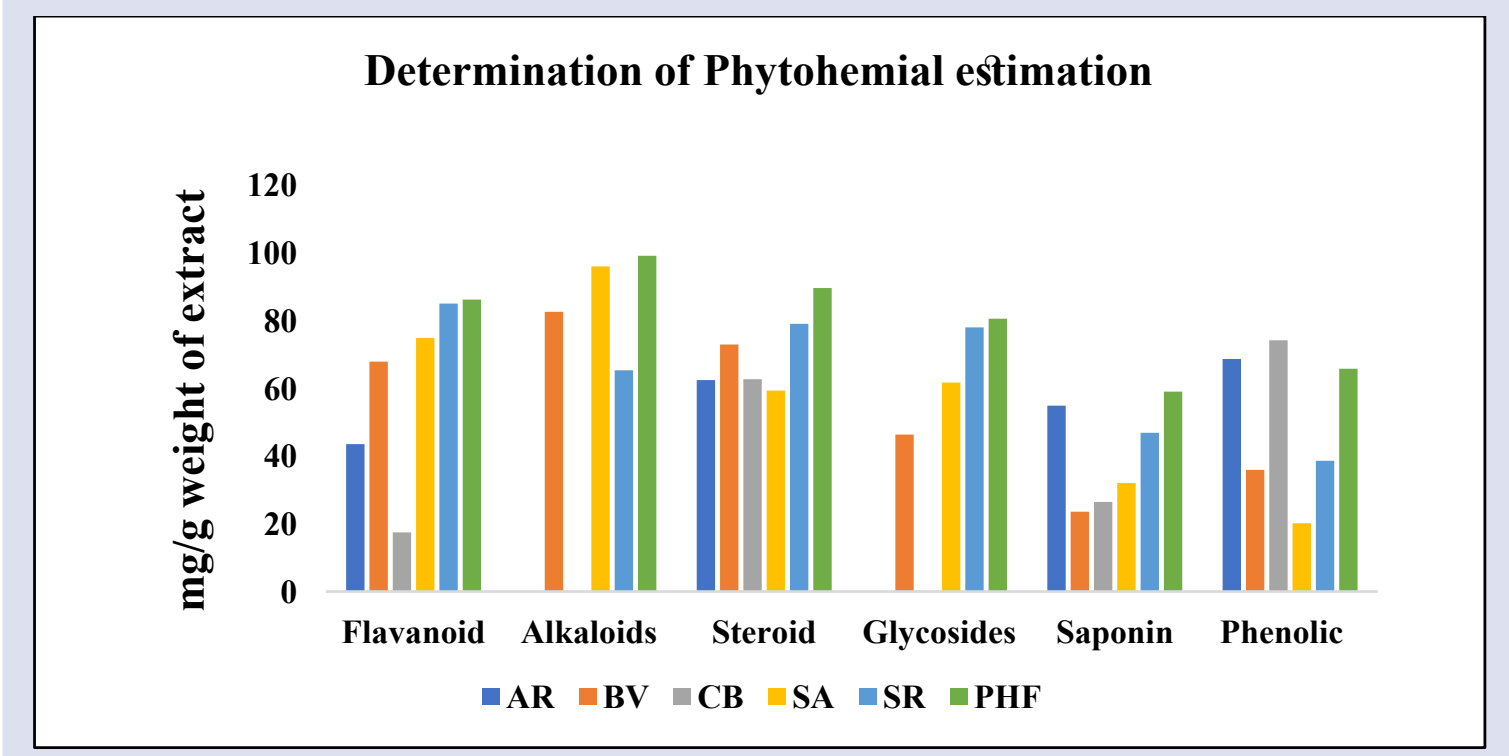

Figure 1: Comparative Profiling of Phytochemical Constituents in Individual plant extracts and PHF. (AR-Asparagus racemosus, BV-Bauhinia variegata, CB-Caesalpinia bonducella, SA-Saraca asoka, SR-Symplococus racemosus, PHF-Polyherbal formulation).

such as 2,2'-Bioxirane, 2-Furanmethanol, 6-Oxabicyclo (3.1.0) Hexan3-one, 4-H-Pyran-4-one, 2,3 dihydro-3,5 dihydroxy-6, Isosorbide, 5-Hydroxy methyl furfural, D-Glucitol, and 1,4-anhydrous and 9,12-Octadecadienoic acid. Bauhinia variegata extract showed the presence of a variety of phytoconstituents such as 2-Furanmethanol, 2(5H)-Furanone 5-methyl-(Identit), Diazene, bis (1, 1-dimethyl ethyl), Benzoic acid, 5-Hydroxy methyl furfural, Hexadecanoic acid, methyl ester, and 9-Octadecenoic acid (Z) methyl ester. Caesalpinia bonducella extract exhibited the presence of $2(3 \mathrm{H})$-Furanone, 5-Methyl, 5-Hydroxy methyl furfural, 9, 12-Octadecadienoic acid methyl, 9, 12-Octadecadienoic acid (z,z)-2-hydroxy-1, Retinol acetate, and Rhodopin. Hydroalcoholic extract of Saraca asoka displayed the presence of Furfural, 2-Furanmethanol, Bicycle $(2,2,1)$ Heptane-2-Carboxyl, Benzoic acid, 5-Hydroxymethyl furfural, and 1,2,3-Benzenetriol. Symplococus racemosus showed the presence of 2-Furancarboxaldehyde, 3, 5-octadien-2-one, Levoglucosenone, 4H-Pyran-4-one, 2,3-dihydro 3,5-dihydroxy-6, 5-Hydroxy methyl furfural, and Phenol 4-Propyl. The polyherbal formulation showed the presence of 2-Furanmethanol, 1-chlorodecane, Tetradecane 1-chloro, Methoxyacetic acid, pentadecyl ester, Hexadecanoic acid, methyl ester, 1, 2-benzene dicarboxylic acid, and 9,12-octadecadienoic acid. This analysis identified the pharmacological activity of reported and nonreported phytochemical compounds. Among the compounds, here mentioned only reported pharmacological activity of compounds. The active principle compounds, their retention time (RT), molecular formula (MF), molecular weight (MW), peak area, and biological activity are presented in Figure 2 and Tabulated in Table 5-10.

\section{In vitro antioxidant activity}

This DPPH assay is based on scavenging of the free radical from the antioxidants, which delivers a diminishing absorbance at 517 $\mathrm{nm}$. All the individual extract and PHF displayed a comparable antioxidant activity with that of standard ascorbic acid at the different concentrations tested $(12.5,25,50,100,200 \mu \mathrm{g} / \mathrm{ml})$. Ascorbic acid was utilized as the standard drug for the estimation of antioxidant activity by the DPPH Scavenging method. The scavenging activity of DPPH free radical assay of standard ascorbic acid and hydroalcoholic extract of A. racemosus, B. variegata, C. bonducella, S. asoka, S. racemosus, and PHF were mentioned in Table11 and Figure 3 (a). This free radical assay observed that all the individual extracts and PHF showed significant DPPH scavenging activity against free radicals. The $\mathrm{H}_{2} \mathrm{O}_{2}$ scavenging assay was perceived and compared with the standard component of ascorbic acid. It is subsequently naturally favorable for cells to control the measure of hydrogen peroxide that is permitted to aggregate. ${ }^{28}$ The antioxidant activity of the $\mathrm{H}_{2} \mathrm{O}_{2}$ assay was depicted in Table 13 and Figure 3(b). Radical scavenging activity in a hydroalcoholic extract of A. racemosus, B. variegata, C. bonducella, S. asoka, S. racemosus, and PHF demonstrate the potential inhibitory effect of radical scavenging activity. The radical scavenging assay of all the individual extract and 

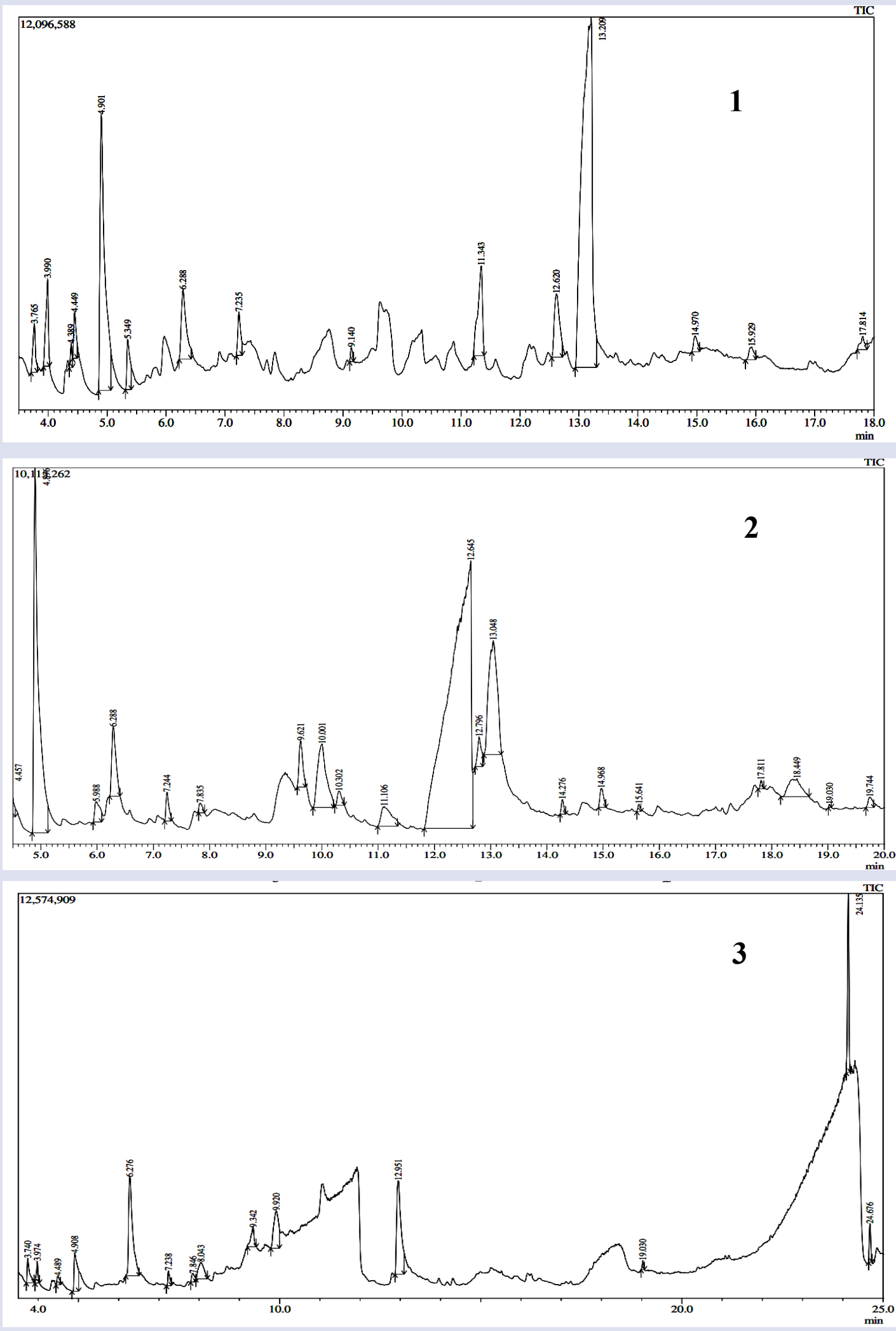


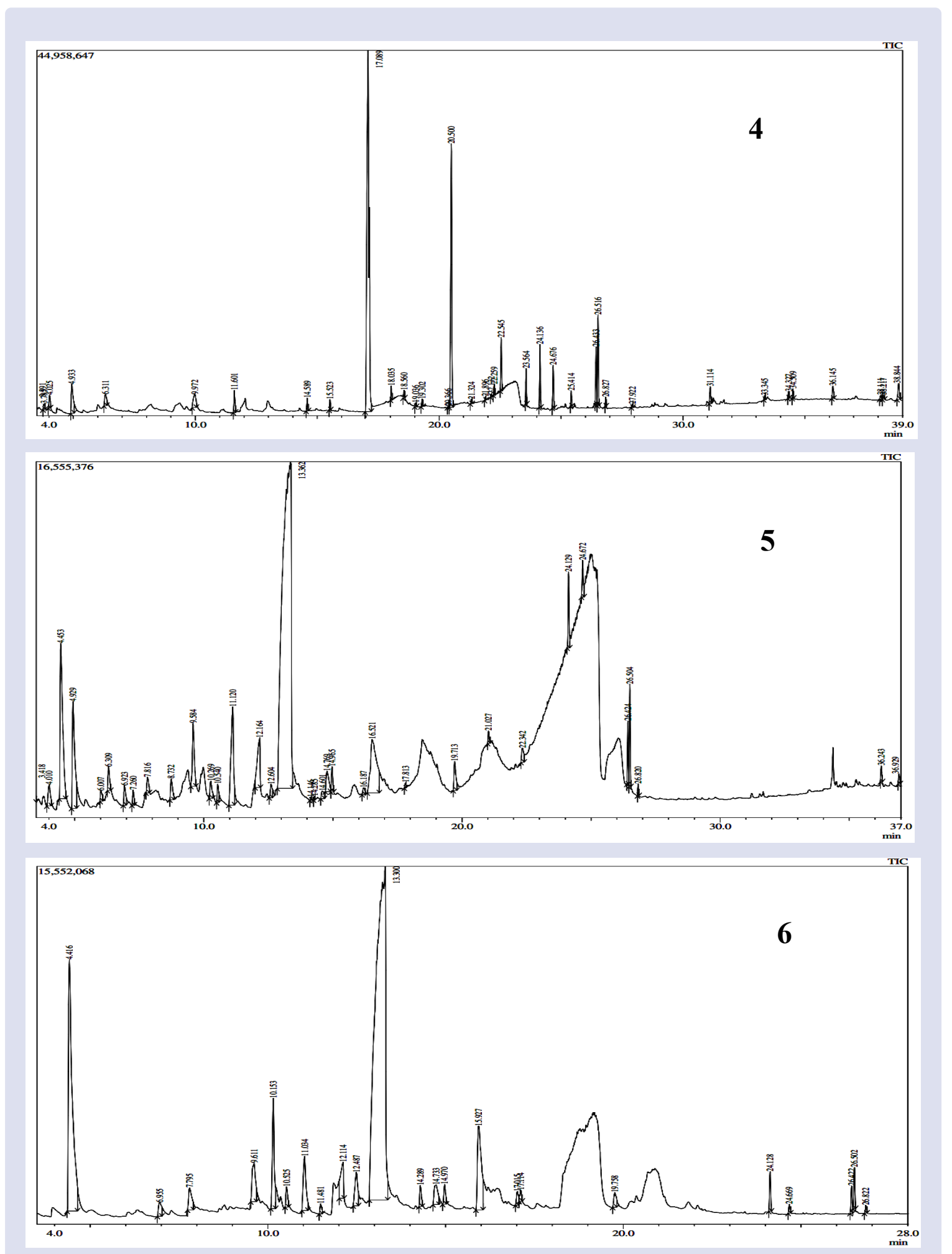

Figure 2: The GC-MS Chromatogram of hydroalcoholic extract of Asparagus racemosus (1), Bauhinia variegata (2), Caesalpinia bonducella (3), Saraca asoka (4), Symplococus racemosus (5) and Polyherbal formualtion. 
Table 5: Compounds identified by GC-MS in Hydroalcoholic extract of Asparagus racemosus.

\begin{tabular}{|c|c|c|c|c|c|c|}
\hline S.no & RT & Name & MF & M.W (g/mol) & Peak area \% & Biological activity \\
\hline 1 & 3.321 & 2,2'-Bioxirane & $\mathrm{C}_{4} \mathrm{H}_{6} \mathrm{O}_{2}$ & 86.09 & 3.05 & Antineoplastic \\
\hline 2 & 4.901 & 2-Furanmethanol & $\mathrm{C}_{5} \mathrm{H}_{6} \mathrm{O}_{2}$ & 98.1 & 10.06 & Antiviral activity \\
\hline 3 & 6.288 & 6-Oxabicyclo (3.1.0) Hexan-3-one & $\mathrm{C}_{7} \mathrm{H}_{12} \mathrm{O}$ & 98.1 & 2.57 & Antibacterial \\
\hline 4 & 11.343 & $\begin{array}{c}\text { 4-H-Pyran-4-one, } 2,3 \text { dihydro-3,5 } \\
\text { dihydroxy-6 }\end{array}$ & $\mathrm{C}_{6} \mathrm{H}_{8} \mathrm{O}_{4}$ & 144.12 & 3.15 & $\begin{array}{l}\text { Antioxidant, automatic nerve activity, } \\
\text { anticancer, anti-inflammatory }\end{array}$ \\
\hline 5 & 12.620 & Isosorbide & $\mathrm{C}_{6} \mathrm{H}_{10} \mathrm{O}_{4}$ & 146.14 & 2.55 & $\begin{array}{c}\text { Anti-inflammatory and cardiovascular } \\
\text { disease }\end{array}$ \\
\hline 6 & 13.209 & 5-Hyroxy methyl furfural & $\mathrm{C}_{6} \mathrm{H}_{6} \mathrm{O}_{3}$ & 126.11 & 27.06 & Anti-oxidant anti-proliferative activity \\
\hline 7 & 20.746 & D-Glucitol, 1,4-anhydro & $\mathrm{C}_{18} \mathrm{H}_{34} \mathrm{O}_{6}$ & 346.459 & 27.81 & Anti-bacterial \\
\hline 8 & 26.424 & 9,12-Octadecadienoic acid & $\mathrm{C}_{19} \mathrm{H}_{34} \mathrm{O}_{2}$ & 294.47 & 3.53 & Anticancer \\
\hline
\end{tabular}

Table 6: Compounds identified by GC-MS in Hydroalcoholic extract of Bauhinia variegate.

\begin{tabular}{|c|c|c|c|c|c|c|}
\hline S.no & RT & Name & MF & M.W (g/mol) & Peak area \% & Biological activity \\
\hline 1 & 4.896 & 2-Furanmethanol & $\mathrm{C}_{5} \mathrm{H}_{6} \mathrm{O}_{2}$ & 98.1 & 13.74 & Antiviral activity \\
\hline 2 & 6.288 & 2(5H)-Furanone 5-methyl-(Identit) & $\mathrm{C}_{5} \mathrm{H}_{6} \mathrm{O}_{2}$ & 98.1 & 2.32 & Antitumor activity \\
\hline 3 & 10.001 & Diazene, bis (1,1-dimethyl ethyl) & $\mathrm{C}_{8} \mathrm{H}_{18} \mathrm{~N}_{2}$ & 142.24 & 4.45 & Anti-phytopathogenic \\
\hline 4 & 12.645 & Benzoic acid & $\mathrm{C}_{7} \mathrm{H}_{6} \mathrm{O}_{2}$ & 122.12 & 44.96 & $\begin{array}{l}\text { Antimicrobial, antiestrogenic, anti- } \\
\text { inflammatory, } \\
\text { anti-platelet aggregating, antiviral, anti- } \\
\text { oxidant, antimutagenic, , antialgal, }\end{array}$ \\
\hline 5 & 13.048 & 5-Hydroxy methyl furfural & $\mathrm{C}_{6} \mathrm{H}_{6} \mathrm{O}_{3}$ & 126.11 & 7.77 & Anti-oxidant anti-proliferative activity \\
\hline 6 & 24.132 & Hexadecanoic acid, methyl ester & $\mathrm{C}_{17} \mathrm{H}_{34} \mathrm{O}_{2}$ & 270.45 & 3.27 & $\begin{array}{l}\text { Anti-oxidant, decrease blood } \\
\text { cholesterol, anti-inflammatory }\end{array}$ \\
\hline 7 & 26.507 & 9-Octadecenoic acid (Z) methyl ester & $\mathrm{C}_{19} \mathrm{H}_{36} \mathrm{O}_{2}$ & 294.47 & 4.46 & Anti-cancer \\
\hline
\end{tabular}

Table 7: Compounds identified by GC-MS in Hydroalcoholic extract of Caesalpinia bonducella.

\begin{tabular}{|c|c|c|c|c|c|c|}
\hline S.no & RT & Name & MF & M.W (g/mol) & Peak area \% & Biological activity \\
\hline 1 & 6.276 & 2(3H)-Furanone, 5-Methyl & $\mathrm{C}_{5} \mathrm{H}_{6} \mathrm{O}_{2}$ & 98.09 & 4.35 & Antimicrobial activity \\
\hline 2 & 12.951 & 5-Hydroxy methyl furfural & $\mathrm{C}_{6} \mathrm{H}_{6} \mathrm{O}_{3}$ & 126.11 & 4.46 & Anti-oxidant anti-proliferative activity \\
\hline 3 & 26.438 & 9,12-Octadecadienoic acid methyl & $\mathrm{C}_{19} \mathrm{H}_{34} \mathrm{O}_{2}$ & 294.47 & 4.74 & Anticancer \\
\hline 4 & 33.496 & 9,12-Octadecadienoic acid (z,z)-2-hydroxy-1 & $\mathrm{C}_{21} \mathrm{H}_{38} \mathrm{O}_{4}$ & 354.52 & 11.53 & Anti-inflammatory, nematocide \\
\hline 5 & 37.191 & Retinol, acetate & $\mathrm{C}_{22} \mathrm{H}_{32} \mathrm{O}_{2}$ & 328.5 & 4.00 & Vitamin A \\
\hline 6 & 38.540 & Rhodopin & $\mathrm{C}_{40} \mathrm{H}_{58} \mathrm{O}$ & 554.9 & 5.10 & $\begin{array}{l}\text { Major compounds in phototrophic } \\
\text { bacteria. }\end{array}$ \\
\hline
\end{tabular}

Table 8: Compounds identified by GC-MS in Hydroalcoholic extract of Saraca asoka.

\begin{tabular}{|c|c|c|c|c|c|c|}
\hline S.no & RT & Name & MF & M.W (g/mol) & Peak area \% & Biological activity \\
\hline 1 & 4.453 & Furfural & $\mathrm{C}_{5} \mathrm{H}_{4} \mathrm{O}_{2}$ & 96.08 & 7.67 & Antimicrobial activity \\
\hline 2 & 4.929 & 2-Furanmethanol & $\mathrm{C}_{5} \mathrm{H}_{6} \mathrm{O}_{2}$ & 98.1 & 4.99 & Antiviral activity \\
\hline 3 & 9.584 & Bicycle $(2,2,1)$ Heptane-2-Carboxyl & $\mathrm{C}_{8} \mathrm{H}_{12} \mathrm{O}_{2}$ & 140.18 & 2.32 & Antioxidant activity \\
\hline 4 & 12.164 & Benzoic acid & $\mathrm{C}_{7} \mathrm{H}_{6} \mathrm{O}_{2}$ & 122.12 & 2.64 & Antifungal activity \\
\hline 5 & 13.362 & 5-Hydroxymethyl furfural & $\mathrm{C}_{6} \mathrm{H}_{6} \mathrm{O}_{3}$ & 126.11 & 54.02 & Anti-oxidant anti-proliferative activity \\
\hline 6 & 16.521 & 1,2,3-Benzenetriol & $\mathrm{C}_{6} \mathrm{H}_{6} \mathrm{O}_{3}$ & 126 & 6.37 & $\begin{array}{l}\text { Antimicrobial, Anti-inflammatory, } \\
\text { Antioxidant, Analgesic, Insecticide, } \\
\text { Anticancer, Cytotoxic }\end{array}$ \\
\hline
\end{tabular}

Table 9: Compounds identified by GC-MS in Hydroalcoholic extract of Symplococus racemosus.

\begin{tabular}{|c|c|c|c|c|c|c|}
\hline S.no & RT & Name & MF & M.W (g/mol) & Peak area \% & Biological activity \\
\hline 1 & 4.416 & 2-Furancarboxaldehyde & $\mathrm{C}_{5} \mathrm{H}_{5} \mathrm{NO}_{2}$ & 111.1 & 16.62 & Antimicrobial \\
\hline 2 & 9.611 & 3,5-octadien-2-one & $\mathrm{C}_{8} \mathrm{H}_{12} \mathrm{O}$ & 124.18 & 2.23 & Antimicrobial \\
\hline 3 & 10.153 & Levoglucosenone & $\mathrm{C}_{6} \mathrm{H}_{6} \mathrm{O}_{3}$ & 126.11 & 3.75 & Antioxidant \\
\hline 4 & 11.034 & $\begin{array}{l}\text { 4H-Pyran-4-one, } 2,3 \text {-dihydro } \\
\text { 3,5-dihydroxy- } 6\end{array}$ & $\mathrm{C}_{8} \mathrm{H}_{8} \mathrm{O}_{4}$ & 144.12 & 2.58 & $\begin{array}{l}\text { Antimicrobial, anti-inflammatory, } \\
\text { antiproliferative }\end{array}$ \\
\hline 5 & 13.300 & 5-Hydroxy methyl furfural & $\mathrm{C}_{6} \mathrm{H}_{6} \mathrm{O}_{3}$ & 126.11 & 56.54 & $\begin{array}{l}\text { Anti-oxidant anti-proliferative } \\
\text { activity }\end{array}$ \\
\hline 6 & 15.927 & Phenol-4-Propyl & $\mathrm{C}_{9} \mathrm{H}_{12} \mathrm{O}$ & 136.19 & 5.62 & Antioxidant activity \\
\hline 1 & 4.416 & 2-Furancarboxaldehyde & $\mathrm{C}_{5} \mathrm{H}_{5} \mathrm{NO}_{2}$ & 111.1 & 16.62 & Antimicrobial \\
\hline 2 & 9.611 & 3,5-octadien-2-one & $\mathrm{C}_{8} \mathrm{H}_{12} \mathrm{O}$ & 124.18 & 2.23 & Antimicrobial \\
\hline
\end{tabular}


Table 10: Compounds identified by GC-MS in Hydroalcoholic extract of Polyheral formulation.

\begin{tabular}{|c|c|c|c|c|c|c|}
\hline S.no & RT & Name & MF & M.W (g/mol) & Peak area \% & Biological activity \\
\hline 1 & 4.933 & 2-Furanmethanol & $\mathrm{C}_{5} \mathrm{H}_{6} \mathrm{O}_{2}$ & 98.1 & 3.16 & Antiviral activity \\
\hline 2 & 17.089 & 1-chlorodecane & $\mathrm{C}_{10} \mathrm{H}_{21} \mathrm{Cl}$ & 176.72 & 45.35 & Ontologies \\
\hline 3 & 20.500 & Tetradecane 1-chloro & $\mathrm{C}_{14} \mathrm{H}_{29} \mathrm{Cl}$ & 232.83 & 18.34 & Antimicrobial activity \\
\hline 4 & 22.545 & Methoxyacetic acid, pentadecyl ester & $\mathrm{C}_{18} \mathrm{H}_{36} \mathrm{O}_{3}$ & 300.5 & 2.63 & Antibacterial activity \\
\hline 5 & 24.136 & Hexadecanoic acid, methyl ester & $\mathrm{C}_{17} \mathrm{H}_{34} \mathrm{O}_{2}$ & 270 & 2.96 & $\begin{array}{c}\text { Antioxidant, antibacterial, } \\
\text { antifungal }\end{array}$ \\
\hline 6 & 24.676 & 1,2-benzenedicarboxylic acid & $\mathrm{C}_{8} \mathrm{H}_{6} \mathrm{O}_{4}$ & 166.13 & 2.11 & $\begin{array}{c}\text { Antimicrobial, Antifouling, } \\
\text { Anti-extended-spectrum } \\
\text { beta-lactamase activity }\end{array}$ \\
\hline 7 & 26.433 & 9,12-octadecadienoic acid & $\mathrm{C}_{18} \mathrm{H}_{36} \mathrm{O}_{2}$ & 284 & 2.64 & $\begin{array}{l}\text { Anti-cancer, antimicrobial } \\
\text { activity }\end{array}$ \\
\hline
\end{tabular}

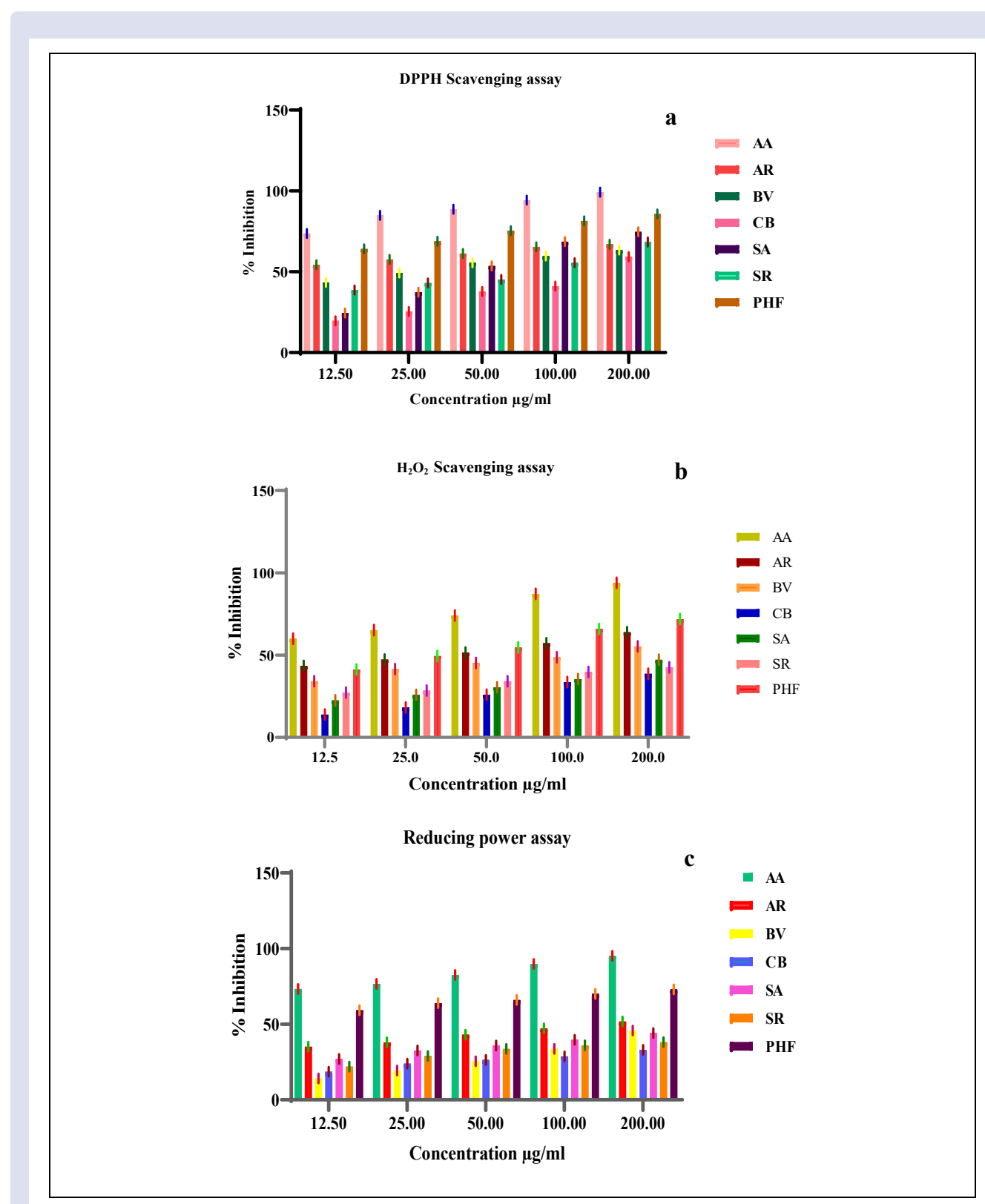

Figure 3: Antioxidant activity with DPPH (a), $\mathrm{H}_{2} \mathrm{O}_{2}$ (b), and Reducing power assay (c)

(AA-Ascorbic acid, AR-Asparagus racemosus, BV-Bauhinia variegata, CB-Caesalpinia bonducella, SA-Saraca asoka, SR-Symplococus racemosus, and PHF-Polyherbal formulation) 
Table 11: DPPH scavenging assay (in \%).

\begin{tabular}{ccccccc}
\hline Conc. $\mu \mathrm{g} / \mathrm{ml}$ & AA (std.) & AR & BV & CB & SA \\
\hline $\mathbf{1 2 . 5}$ & $57.3 \pm 0.789$ & $54.51 \pm 0.325$ & $43.28 \pm 0.286$ & $19.58 \pm 0.08$ & $24.46 \pm 0.721$ & $38.53 \pm 0.736$ \\
$\mathbf{2 5}$ & $64.73 \pm 0.623$ & $57.65 \pm 0.786$ & $49.24 \pm 0.05$ & $26.38 \pm 1.073$ & $37.53 \pm 0.586$ & $43.81 \pm 0.987$ \\
$\mathbf{5 0}$ & $72.88 \pm 0.928$ & $61.41 \pm 0.457$ & $56.09 \pm 0.609$ & $37.47 \pm 1.159$ & $54.32 \pm 0.644$ & $44.81 \pm 0.946$ \\
$\mathbf{1 0 0}$ & $85.13 \pm 2.44$ & $66.86 \pm 1.11$ & $60.7 \pm 1.021$ & $42.47 \pm 1.22$ & $68.54 \pm 1.16$ & $55.22 \pm 0.575$ \\
$\mathbf{2 0 0}$ & $99.34 \pm 0.185$ & $65.15 \pm 1.661$ & $65.02 \pm 1.362$ & $60.57 \pm 1.103$ & $74.16 \pm 0.575$ & $68.81 \pm 0.317$
\end{tabular}

Values were in mean \pm standard deviation, $\mathrm{n}=3$

Table 12: Hydrogen peroxide assay (in \%).

\begin{tabular}{|c|c|c|c|c|c|c|c|}
\hline Conc. $\mu \mathrm{g} / \mathrm{ml}$ & AA (std.) & AR & BV & CB & SA & SR & PHF \\
\hline 12.5 & $59.98 \pm 0.545$ & $43.58 \pm 0.545$ & $34.69 \pm 1.056$ & $14.21 \pm 0.638$ & $22.96 \pm 0.752$ & $27.37 \pm 0.495$ & $42.02 \pm 0.75$ \\
\hline 25 & $65.66 \pm 0.929$ & $47.28 \pm 0.37$ & $41.94 \pm 0.645$ & $17.99 \pm 0.849$ & $25.96 \pm 0.939$ & $28.48 \pm 0.435$ & $49.6 \pm 0.125$ \\
\hline 50 & $74.87 \pm 0.815$ & $52.07 \pm 0.676$ & $46.02 \pm 0.848$ & $26.12 \pm 0.305$ & $31.4 \pm 0.827$ & $34.28 \pm 0.561$ & $55.067 \pm 0.459$ \\
\hline 100 & $87.21 \pm 0.27$ & $57.16 \pm 0.49$ & $48.82 \pm 0.845$ & $33.85 \pm 0.297$ & $35.58 \pm 0.511$ & $39.83 \pm 0.34$ & $65.85 \pm 0.58$ \\
\hline 200 & $93.97 \pm 0.73$ & $63.96 \pm 0.07$ & $55.84 \pm 0.861$ & $38.75 \pm 0.265$ & $47.21 \pm 0.696$ & $42.84 \pm 0.27$ & $72.12 \pm 0.694$ \\
\hline
\end{tabular}

Values were in mean \pm standard deviation, $\mathrm{n}=3$

Table 13: Reducing power assay (in \%).

\begin{tabular}{|c|c|c|c|c|c|c|c|}
\hline Conc. $\mu \mathrm{g} / \mathrm{ml}$ & AA (std.) & AR & BV & CB & SA & SR & PHF \\
\hline 12.5 & $73.25 \pm 0.451$ & $35.13 \pm 0.141$ & $14.17 \pm 0.775$ & $18.55 \pm 0.236$ & $26.79 \pm 0.767$ & $21.83 \pm 0.564$ & $59.2 \pm 0.235$ \\
\hline 25 & $76.69 \pm 1.039$ & $37.94 \pm 0.207$ & $19.41 \pm 0.223$ & $23.93 \pm 0.679$ & $32.67 \pm 0.679$ & $29.04 \pm 0.103$ & $63.86 \pm 0.869$ \\
\hline 50 & $82.57 \pm 0.38$ & $43.1 \pm 0.478$ & $25.48 \pm 0.373$ & $26.35 \pm 0.58$ & $35.95 \pm 0.842$ & $33.73 \pm 0.584$ & $65.97 \pm 0.512$ \\
\hline 100 & $89.8 \pm 0.68$ & $47.23 \pm 0.5$ & $33.66 \pm 0.608$ & $28.77 \pm 0.911$ & $39.7 \pm 0.634$ & $35.97 \pm 0.43$ & $70.08 \pm 0.61$ \\
\hline 200 & $95.2 \pm 0.556$ & $51.82 \pm 0.345$ & $45.76 \pm 0.723$ & $33.09 \pm 0.404$ & $43.92 \pm 0.369$ & $37.63 \pm 0.631$ & $73.02 \pm 0.881$ \\
\hline
\end{tabular}

Values were in mean \pm standard deviation, $n=3$

PHF was compared to ascorbic acid it as mention in Table 12 and Figure 3 (c). Selected medicinal plants and PHF were compared to the ascorbic acid standard it gives good scavenging inhibition against free radicals it as shown in Figure 3. In this activity hydroalcoholic extract of all the selected medicinal plants and its polyherbal formulation showed unresolved scavenging properties on DPPH, reducing power assay, and $\mathrm{H}_{2} \mathrm{O}_{2}$ radical activities. In accumulation, TPC and TFC of the individual plant extracts and PHF were evaluated. It was detected that individual plants extract and PHF confined rich source of flavonoid and phenolic content that capacity has reported for the strong antioxidant activity detected against the free radicals. These results exposed that selected medicinal plant extracts and polyherbal formulation have various phytochemical constituents which might be for many pharmacological activities. Nevertheless, because of the above-introduced results, selected medicinal plants and their PHF cloud be explored as a potential new wellspring of natural antioxidants in the food, nutraceuticals, pharmaceutical and cosmetic industry. ${ }^{28}$

\section{CONCLUSION}

There is a requirement for a time about the logical assessment of novel polyherbal formulation for upcoming generations. The improvement of new polyherbal formulation has been prosperous after a wide literature review. Standardization of herbal medication is a vital significance in initiating its proper identity, purity, quality, and therapeutic efficacy. The macroscopic, physicochemical, qualitative, and quantitative phytochemical analyses are the confirmatory tests for standardization and quality control. Phytochemical screening revealed the presence of various constituents and estimation of bioactive compounds confirmed the high concentration of all the bioactive contents in all the individual plant extract when compared to the polyherbal formulation. Antioxidant activity of all the individual extract and polyherbal formulation showed the highest scavenging activities against $\mathrm{DPPH}$, radical scavenging, and hydrogen peroxide assay. A GC-MS result of all the individual extract and polyherbal formulation contains various bioactive components and it's suggested as a PHF of phytopharmaceutical importance. In conclusion, the present study can be used as reference information for proper identification, authentication, and in vitro antioxidant assay of a novel PHF can be explored for its applications in the prevention of free radical related disease.

\section{CONFLICTS OF INTEREST}

None.

\section{ABBREVIATIONS}

A. racemosus and $\mathrm{AR}$ - Asparagus racemosus; B. variegata and $\mathrm{BV}-$ Bauhinia variegata; C. bonducella and CB - Caesalpinia bonducella; S. asoka and SA - Saraca asoka; S. racemosus and SR - Symplococus racemosus; PHF - Polyherbal formulation; TAC: Total alkaloid content; TFC: Total flavonoid content; TGC: Total glycoside content; Total steroidal content; TPC: Total phenolic content; DPPH -2, 2 - diphenyl - 1picryl hydrazyl; $\mathrm{IC}_{50}$ : Concentration of samples resulting in $50 \%$ inhibition; GAE: Gallic acid equivalent, std.: Standard; $\mathrm{H}_{2} \mathrm{O}_{2}$ : Hydrogen peroxide; GC-MS: Gas chromatography - Mass spectroscopy.

\section{REFERENCES}

1. Sahoo S, Ghosh G, Das D, Nayak S. Phytochemical investigation and in vitro antioxidant activity of an indigenous medicinal plant Alpinia nigra BL Burtt. Asian Pac J Trop Biomed. 2013;3(11):871-6.

2. Mahdi-Pour B, Jothy SL, Latha L, Chen Y, Sasidharan S. Antioxidant activity of methanol extracts of different parts of Lantana camara. Asian Pac J Trop Biomed. 2012;2(12):960-5

3. Deepak J, Anurekha J. Development of polyherbal with antioxidant activity. Asian J Pharm Clin Res. 2018;11(8):483-5.

4. Alok S, Jain SK, Verma A, Kumar M, Mahor A, Sabharwal M. Plant profile,

5. Phytochemistry and pharmacology of Asparagus racemosus (Shatavari): A review. Asian Pac J of Trop Dis. 2013;3(3):242-51.

6. Negi A, Sharma N, Singh MF. Spectrum of pharmacological activities from Bauhinia variegata: a review. J Pharm Res. 2012;5(2):792-7. 
7. Singh $V$, Raghav PK. Review on pharmacological properties of Caesalpinia bonduc L. Int J Med Arom Plants. 2012;2(3):514-30

8. Pradhan P, Joseph L, Gupta V, Chulet R, Arya H, Verma R, Bajpai A. Saraca asoca (Ashoka): a review. J Chem Pharm Res. 2009;1(1):6271.

9. Bhusnar HU, Nagore DH, Nipanikar SU. Phytopharmacological profile of Symplocos racemosa: a review. Pharmacologia. 2014;5(2):76-83.

10. Gupta VB, Manjusha R, Ravishankar B, Harisha CR, Shukla VJ, Khant DB. Pharmacognostical and physicochemical analysis of pathyadivarti-A polyherbal ayurvedic formulation. Int J Pharm \& Life Sci. 2012;3(4):1643-9.

11. Vidya NV, Bineesh EP, DB V. Pharmacognostical and pharmaceutical analysis of triphaladi compound-an Ayurvedic Polyherbal Formulation for Shushkakshipaka (Dry Eye). World J Pharm Res. 2020, 9(6); 230515.

12. Mohanty A, Das C, Dash S, Sahoo DC. Physico-chemical and antimicrobial study of polyherbal formulation. Pharm Glob. 2010, 4 (04). 1189-99.

13. Shivatare RS, Pande AS, Bhusnar HU, Kadam PV, Yadav KN, Patil MJ. Standardization of Narasimha Churna: A Poly-Herbal Formulation. Asian J Biomed Pharm Sci. 2013;3(23):23-7.

14. Garg P, Garg R. Phytochemical screening and quantitative estimation of total flavonoids of Ocimum sanctum in different solvent extract. Pharma Innov. 2019; 8(2);16-21.

15. Rao BG, Rao PU, Rao ES, Rao TM. Studies on phytochemical constituents, quantification of total phenolic, alkaloid content and In-vitro anti-oxidant activity of Thespesia populnea seeds. Free Rad Antiox. 2011;1(4):56-61.

16. Kim E, Goldberg M. Serum cholesterol assay using a stable Liebermann-Burchard reagent. CliniChem. 1969;15(12):1171-9.

17. Solich P, Sedliakova V, Karlíček R. Spectrophotometric determination of cardiac glycosides by flow-injection analysis. Anal Chim Acta. 1992;269(2):199-203.

18. Nandhini S, Ilango K. Comparative Study on Pharmacognostical, Phytochemical Investigations and Quantification of Vasicine Content in the Extracts of Adhatoda vasica Nees and Adhatoda beddomei $C B$ Clarke. Pharmacogn J. 2020;12(4): 884-96.
19. Sembiring EN, Elya B, Sauriasari R. Phytochemical screening, total flavonoid and total phenolic content and antioxidant activity of different parts of Caesalpinia bonducella (L.) Roxb. Pharmacogn J. 2018;10(1): 123-7.

20. Gerige SJ, Gerige MK, Rao M. GC-MS Analysis of Nigella sativa seeds and antimicrobial activity of its volatile oil. Braz Arch Biol Technol. 2009:52(5):1189-92.

21. Uekusa K, Ono T, Hayashida M, Nihira M, Ohno Y. GC/MS analysis of an herbal dietary supplement containing ephedrine. Leg. Med. 2009;11(1):573-5.

22. Vadivel V, Ravichandran N, Rajalakshmi P, Brindha P, Gopal A, Kumaravelu C. Microscopic, phytochemical, HPTLC, GC-MS and NIRS methods to differentiate herbal adulterants: Pepper and papaya seeds. J Her Med. 2018;1 (11):36-45.

23. Ezhilan BP, Neelamegam R. GC-MS analysis of phytocomponents in the ethanol extract of Polygonum chinense L. Pharmacog Res. 2012;4(1):11-4.

24. Madhu SE, Sreeja H, Priya JS. A preliminary study on phytochemical, antioxidant and cytotoxic activity of leaves of Naregamiaalata Wight \& Arn. Mater Today. 2020; 25(2): 343-8.

25. Ruch RJ, Cheng SJ, Klaunig JE. Prevention of cytotoxicity and inhibition of intercellular communication by antioxidant catechins isolated from Chinese green tea. Carcinogenesis. 1989;10(6):1003-8.

26. Saumya SM, Mahaboob BP. In vitro evaluation of free radical scavenging activities of Panax ginseng and Lagerstroemia speciosa: a comparative analysis. Int J Pharm Pharm Sci. 2011;3(1):165-9.

27. Gülçin İ, Küfrevioğlu Öİ. Determination of in vitro antioxidant activity of fennel (Foeniculum vulgare) seed extracts. Food Sci. 2003; 36(2):263-71.

28. Meriga B, Mopuri R, MuraliKrishna T. Insecticidal, antimicrobial and antioxidant activities of bulb extracts of Allium sativum. Asian Pacific J Trop Medi. 2012;5(5):391-5.

29. Sahoo S, Ghosh G, Das D, Nayak S. Phytochemical investigation and in vitro antioxidant activity of an indigenous medicinal plant Alpinia nigra BL Burtt. Asian Pac J Trop Biomed. 2013;3(11):871-6. 


\section{GRAPHICAL ABSTRACT}

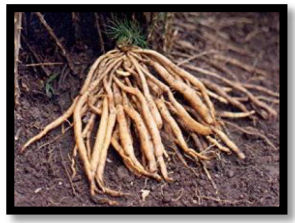

Asparagus racemosus

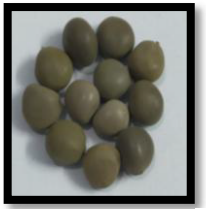

Caesalpinia bonducella

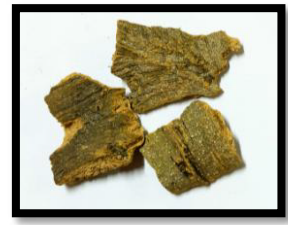

Bauhinia variegata

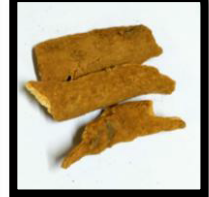

Symplococus racemosus

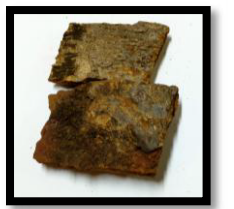

Saraca asoka

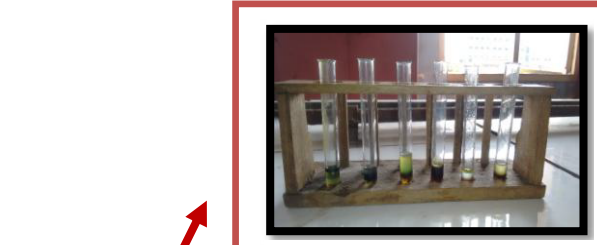

Phytochemical Analysis

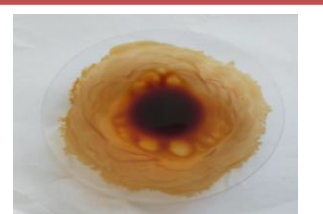

Polyherbal extract

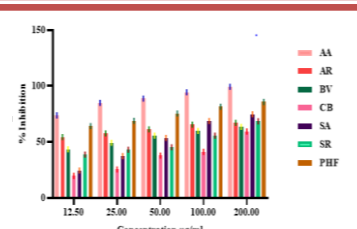

Antioxidant Activity
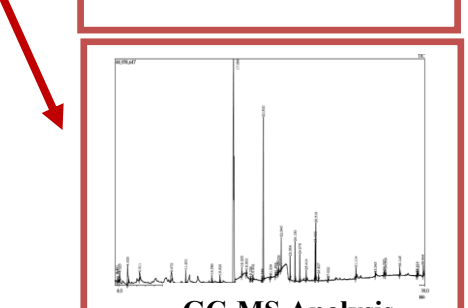

GC-MS Analysis

\section{ABOUT AUTHORS}

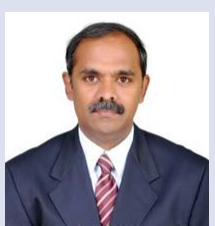

Dr. K. Ilango received his Ph.D. in Pharmaceutical Sciences from Sri Ramachandra Institute Higher Education and Research (SRIHER), Porur, Chennai and Master's degree from Birla Institute of Technology and Science (BITS), Pilani, Rajasthan and graduated from Annamalai University, Chidambaram. His academic journey in SRM began in the year 1994. Since then, Dr. K. Ilango's involvement in Academics and Research had been remarkable. He has made significant scientific publications in peer reviewed National and International journals. Currently he is working as Professor, Department of Pharmaceutical Chemistry, SRM College of Pharmacy, Faculty of Medicine and Health Sciences, SRM Institute of Science and Technology (SRMIST), Chennai and his contribution and sharing of knowledge has benefited several aspiring students.

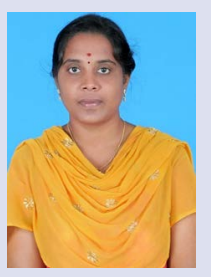

Mrs. K. Shalini has completed her Bachelors of Pharmacy (2010-2014) and Masters of Pharmacy (Pharmacognosy - 2015 to 2017) form College of Pharmacy, Madras Medical College, Chennai - 600003. She is currently pursuing Ph.D in Pharmacy under the supervision of Dr. K. Ilango at SRM College of Pharmacy, SRM Institute of Science and Technology (SRMIST), Kattankulathur - 603203.

Cite this article: Shalini K, Ilango K. Preliminary Phytochemical Studies, GC-MS Analysis and In vitro Antioxidant Activity of Selected Medicinal Plants and its Polyherbal Formulation. Pharmacog J. 2021;13(3): 648-59. 